\title{
THE MINES OF LAURIUM
}

by

Duncan R. Derry

\begin{abstract}
A brief historical sketch of the geology and mining activities in the Laurium area of Greece. These ancient mines have yielded silver and lead deposits for over two and a half thousand centuries now, and still offer potential for future exploration and development.
\end{abstract}

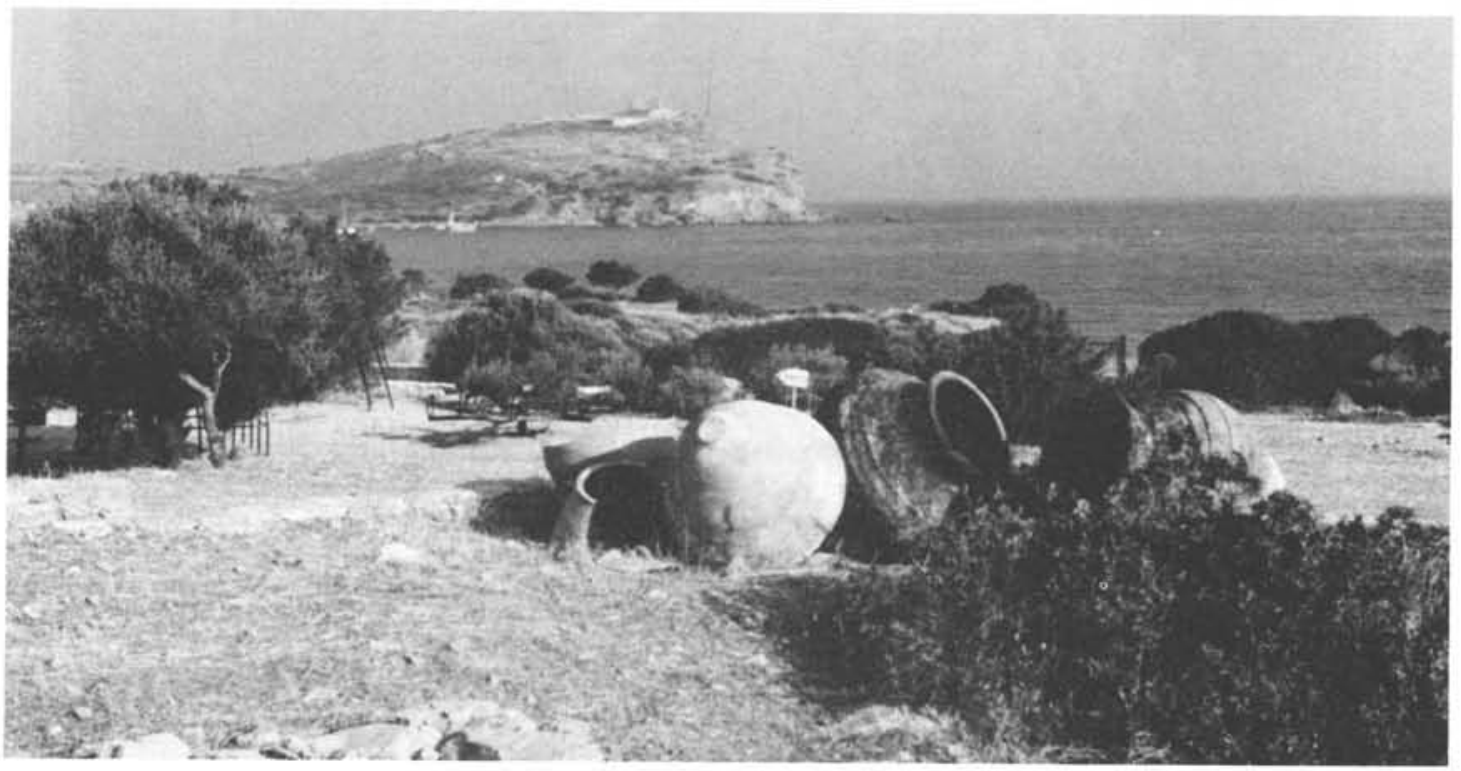

View toward the cape and Temple of Sounion. In the foreground is the site of an ancient mining village.

\section{Historical Notes}

Except for a few intervals, the Laurium area, some $50 \mathrm{kms}$ $\mathrm{SE}$ of Athens, has been a centre of active silver and lead mining during the past 2500 years or more. During the 5th and 4 th centuries B.C., Mediterranean trade was based on a silver rather than a gold currency. The fact that Athens had nearby access to silver-lead deposits (and zinc, for which they had no use at the time and did not recover) had a fundamental bearing on Athens' rise to industrial prominence, which later led to its leadership in the arts and in philosophy.

During some critical periods in Athens' wars with the Persians and with neighbouring states, the Athenians were able to finance the building of navies with profits from the silver mines of the area. These extended from east of Laurium (alternatively Laureion) south to Sounium (Sounion), to the cape at the extreme end of the Attica Peninsula where the ruins of a temple still stand.

Almost from the start of Athenean history, the mines were owned by the state, but individual citizens were permitted to lease them or prospective mining areas under an arrangement whereby they paid the state a fee (the amount depending on its value) for a lease of three to seven years' duration, and some annual tax or royalty.

Thirty-five years ago, archaeologists from the U.S.A. were exploring the Athenean Agora - the market-place and administrative centre of ancient Athens north of the Acropolis - and found the broken remains of some stone tablets bearing mineleasing records. Dated between 367 and 312 B.C., they contain the names of the lessees and detailed descriptions of the areas leased. Though some pieces are missing, enough can be pieced together to recognize places in the Laurium and Sounium areas where mining was carried out at that time and which continue to receive attention today. Figure 1 shows an example of one of these records, with a few names missing, taken from Margaret Crosby, 1950, The Leases of the Laureion Mines: Hesperia, v. XIX, No. 3.

EPISODES, Vol. 1980, No. 4

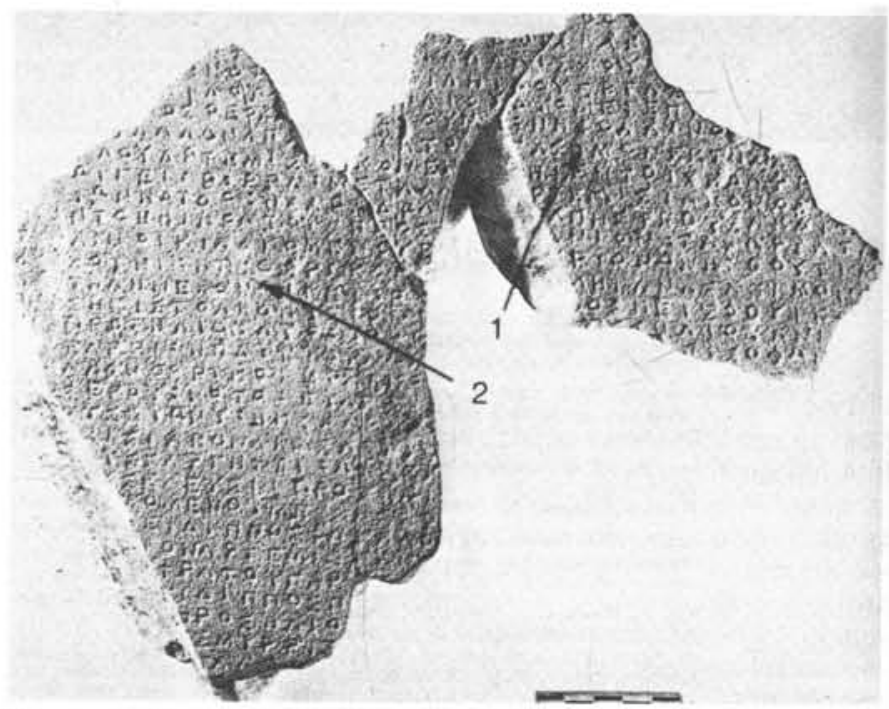

Figure 1. On plate 93 of Hesperia (see reference in text), in translation: (1) "At Thalinos, Thoutimides of Sounion registered from the stele of Euboulos, the ergasimon mine* Artemisiakon in Nape (which is) in the property of ---, of which the boundaries are, at the north, the Artemisiakon mine which is being worked by ---, at the south, the gully which runs from Nape and the workshop of Epikrates, at the east, the property of Teleson and his house, at the west, a workshop, the lessee, Thoutimides son of Phanias of Sounion, (the price) 150 drachmai." (2) (* The "ergasimon mine" means one which was previously operated and on which an extension of the lease is being granted.) 


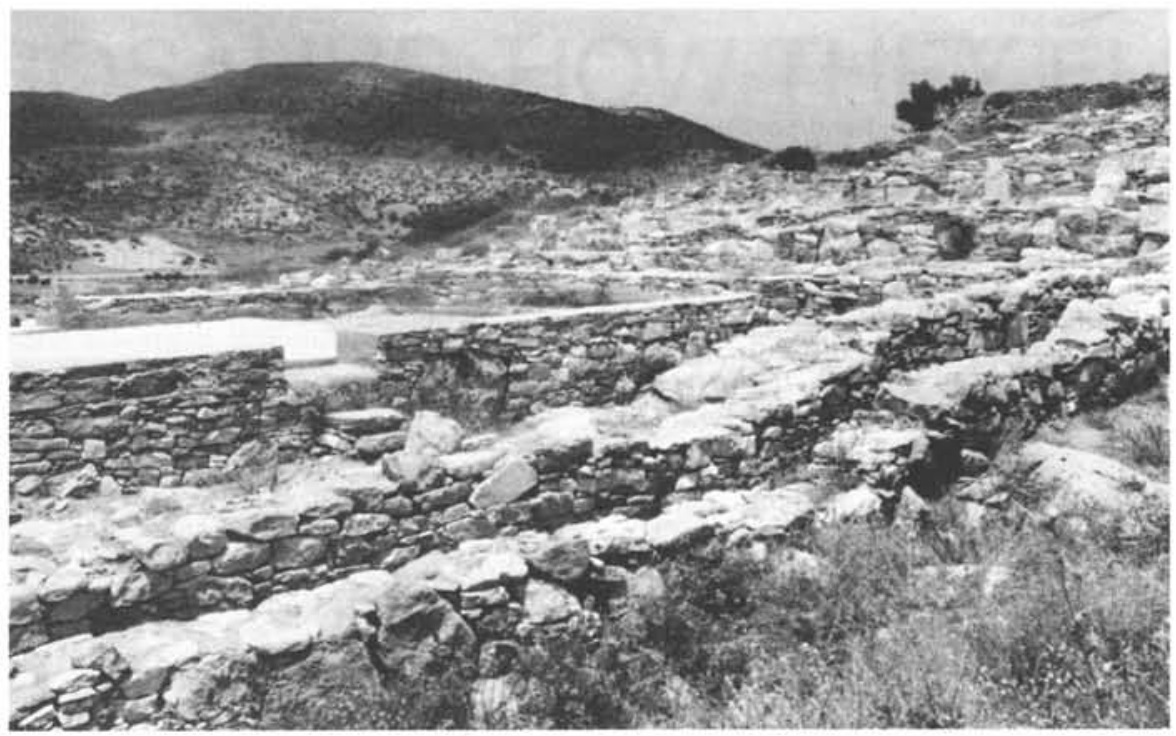

Remains of the ancient city of Laurium.

While mining declined toward the end of the 3rd century B.C., it was revived again during the Roman occupation and many tons of tailings from this period still lie in the bay at Laurium. With the fall of the Roman Empire, mining virtually died out until about 1860, when a group of Frenchmen re-discovered the mineralized area and started mining operations under the company "Mines Françaises de Laurium". It continued production for over a hundred years, and at present, the same French company (now part of the IMETAL group) is reviewing the possibility of finding new reserves sufficient to instigate yet another phase of leadzinc-silver mining in this historic area.

Aside from this company's efforts, an attempt was made shortly after World War II (as part of the attempt to revive Greece's economy following the civil war that ensued after the departure of the German occupying forces) to revive mining nearer the east coast and towards Sounium. Ventures Limited (now part of Falconbridge) was active in this phase and also made an attempt to recover and treat Roman tailings in Laurium Bay. The latter operation was not successful due to the fact that the grains of galena had become too oxidized to be satisfactorily recovered by flotation. Efforts to find new ore were only partially successful and the operation soon closed down.

As noted above, Athenian organization of mining was very advanced from a legislative point of view. The actual mining was evidently done entirely by slaves acquired by the lessee. Even the mine manager was a highly sought-after slave, apparently treated with considerable respect. Male slaves were responsible for the mining, the ore being transported from the face to the acit portal or shaft by boys, who dragged it in baskets; female slaves sorted it at the adit portal or the shaft head. Crosscuts through non-ore rock were driven no higher or wider than they had to be for access. Once the crosscut hit ore, the gallery opened up to the height and width of mineralization. One can see notches in the walls where the ancient miners had placed their oil lamps and, from the successive positions of these, it would appear that the advance during a shift was about $10 \mathrm{cms}$.

\section{Geology}

The lead-zinc-silver mineralization is associated with three disconformable contacts in a series of flat to gently dipping sediments in which limestone and marbles predominate. While no radiometric dating seems to have been carried out and fossils are absent, it is believed that the lowest beds are probably Jurassic in age and the youngest in the series are Middle Cretaceous. The three "contacts" are limestone or marble overlain by what are loosely termed "schists", and

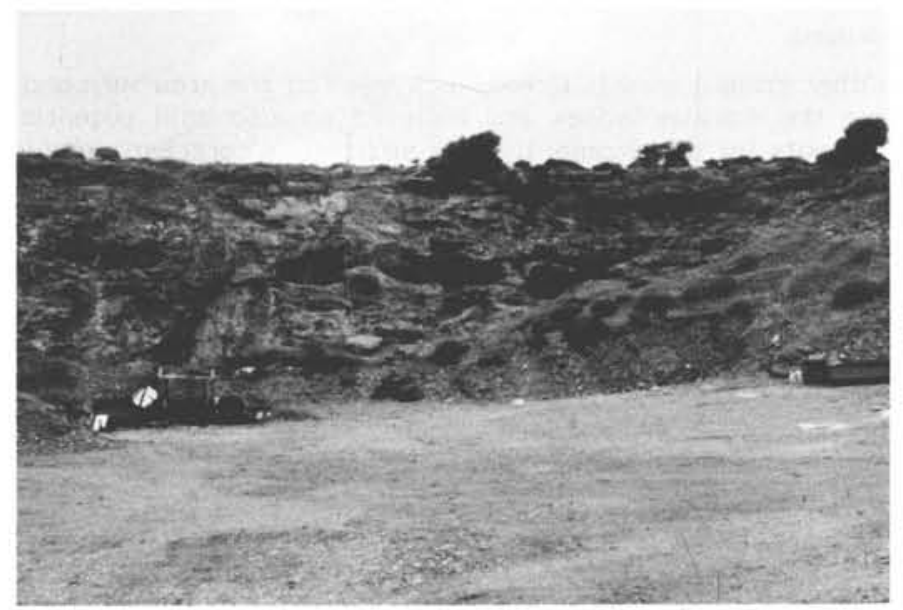

Ancient mine workings exposed in the face of a recent open pit.

each appears to represent a period of re-emergence from the sea followed by erosion.

These schists used to be regarded as pelitic sediments, but more evidence assembled by the French and Greek geologists involved in recent mining (during the last 10 to 15 years) indicates that at least parts of the schists represent tuffs and other products of volcanic activity. Granite and related material intrude at least the older members, and felsic dikes cut the whole series.

The ratio of silver to lead along the main contacts was about 12 grams silver per ton to each one percent lead, but some of the local concentrations (evidently in the openings of former karst topography) are secondary and much richer in silver. Most of the ancient Athenean work was on the "first" (uppermost) contact or in the local, richer karst concentrations which tend to be of limited vertical and horizontal extent. The ancient miners, however, made fairly advanced geological deductions with regard to the association of ore and buried schist/limestone contacts. For example, a pit on a mined-out karst shoot might be extended downwards in search for the contact-type of ore. Walking along a new gallery on such a contact in the French workings, one comes on a small circular "raise" to surface which was originally a prospect shaft put down by the ancients to test the buried contact. 


\section{Treatment of Ores}

The treatment of ore was as follows: after hand sorting and hand crushing, a gravity concentrating washing device was used in which sloping channels, with a pit at each corner to catch the heavy product, surrounded a flat or slightly convex platform on which the concentrates were placed to drain and dry out. Water was thus conserved as much as possible, the area being very dry in summer, with no natural reservoirs. Lines of ancient cisterns, one leading into another, may be seen in valleys above the washing plants, showing the efforts that were required to save rainfall for a sufficient water supply.

The concentrates were removed from the washing plants (probably after several re-treatments) and taken to a local furnace for smelting. This produced metallic lead of good quality. The recovery of the silver from the lead was carried out by a method corresponding to our cupellation, and the recovery of silver, on a percentage basis, seems to have been remarkably high.

\section{Current Exploration}

The French subsidiary of IMETAL is still actively exploring for additional ore in the area, concentrating mainly on the "second contact", largely concealed by overlying beds. Geophysical and geochemical surveys have been conducted to delineate targets along the contact, some of which are being drilled.

Other groups, mostly Greek, own much of the area surrounding the working mines and believed to also hold potential deposits for development. It is difficult to forecast possible success or failure with any more certainty than that voiced by Xenophon in the 4 th century B.C. and quoted in a company report by J.P. Lenoble and A. Morikis: ".... and we could now, as before, mine new galleries. Nobody could say, with full knowledge of the facts, if there was more ore in the mined deposits than in the unexplored ones" (translation anonymous). Nevertheless, an area with such a history of successive mining revivals is still potentially good for fur ther exploration using modern techniques.

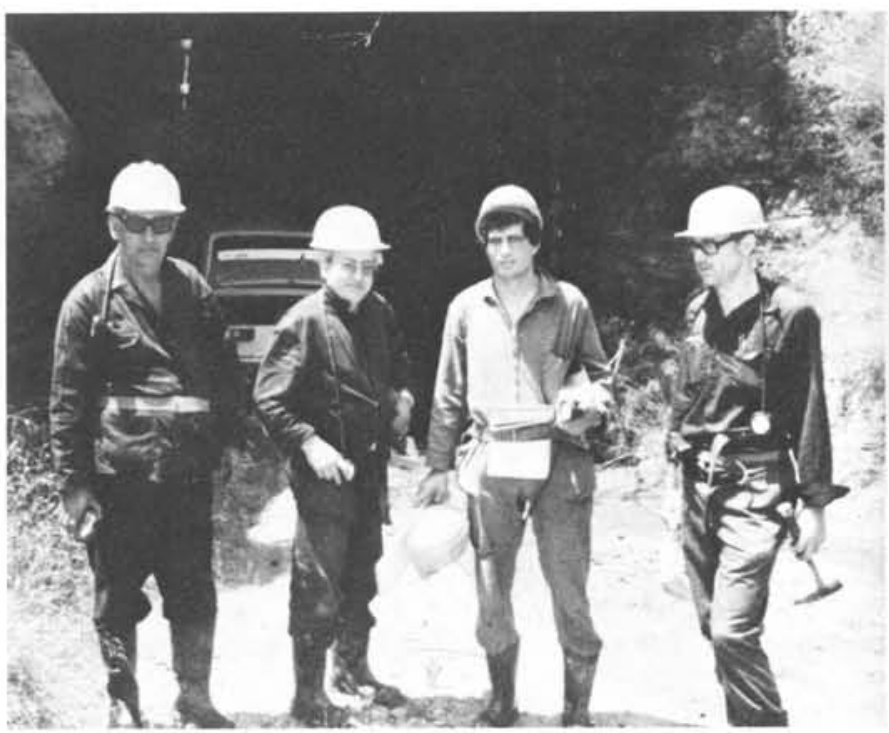

In the adit portal of a modern gallery, ancient workings are intersected in places.
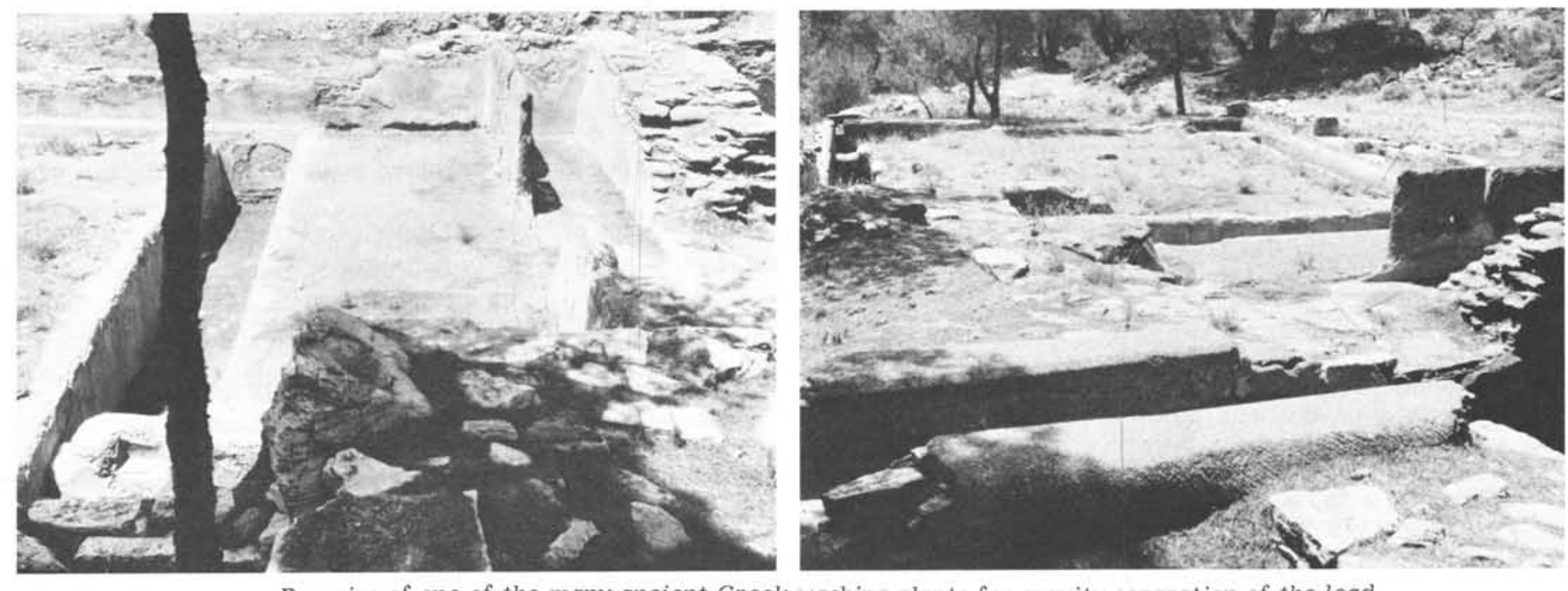

Remains of one of the many ancient Greek washing plants for gravity separation of the lead.

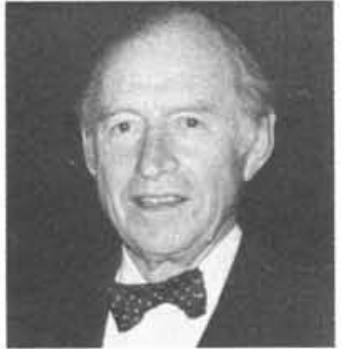

EPISODES, Vol. 1980, No. 4
ABOUT THE AUTHOR: Dr. Duncan Derry joined Ventures Ltd. in 1935 and, after war service with the Royal Canadian Air Forces, became the Company's chief geologist. In 1954 he became President of Rio Canadian Exploration and in 1960 established his own consulting firm, now called Derry, Michener and Booth, in Toronto, Canada. A Past President of both the Geological Association of Canada and the Society of Economic Geologists, Dr. Derry has just published a "Concise World Atlas of Geology and Mineral Deposits" (see Book Reviews section). 